\title{
"The relationship between external debt and economic growth: empirical evidence from Ukraine and other emerging economies"
}

\begin{tabular}{|c|c|}
\hline AUTHORS & $\begin{array}{l}\text { Inna Shkolnyk (D https://orcid.org/0000-0002-5359-0521 } \\
\text { R http://www.researcherid.com/rid//-7368-2018 } \\
\text { Viktoriia Koilo } \mathbb{D} \text { https://orcid.org/0000-0001-7953-9970 } \\
\text { R https://publons.com/researcher/1939207/viktoriia-koilo/ }\end{array}$ \\
\hline ARTICLE INFO & $\begin{array}{l}\text { Inna Shkolnyk and Viktoriia Koilo (2018). The relationship between external debt } \\
\text { and economic growth: empirical evidence from Ukraine and other emerging } \\
\text { economies. Investment Management and Financial Innovations, 15(1), 387-400. } \\
\text { doi:10.21511/imfi.15(1).2018.32 }\end{array}$ \\
\hline DOI & http://dx.doi.org/10.21511/imfi.15(1).2018.32 \\
\hline RELEASED ON & Friday, 06 April 2018 \\
\hline RECEIVED ON & Saturday, 03 March 2018 \\
\hline ACCEPTED ON & Tuesday, 03 April 2018 \\
\hline LICENSE & $\begin{array}{l}(c)) \text { EY-No } \\
\text { This work is licensed under a Creative Commons Attribution-NonCommercial } 4.0 \\
\text { International License }\end{array}$ \\
\hline JOURNAL & "Investment Management and Financial Innovations" \\
\hline ISSN PRINT & $1810-4967$ \\
\hline ISSN ONLINE & $1812-9358$ \\
\hline PUBLISHER & LLC "Consulting Publishing Company "Business Perspectives" \\
\hline FOUNDER & LLC "Consulting Publishing Company "Business Perspectives" \\
\hline
\end{tabular}

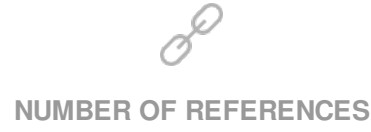

29

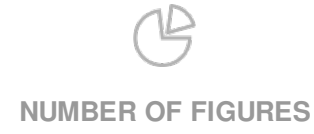

5
$-=-$
$-=-$

NUMBER OF TABLES

5

(C) The author(s) 2023. This publication is an open access article. 


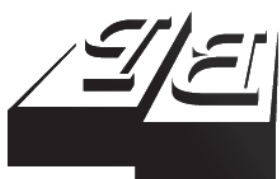

BUSINESS PERSPECTIVES

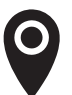

LLC "CPC "Business Perspectives" Hryhorii Skovoroda lane, 10, Sumy, 40022, Ukraine

www.businessperspectives.org

Received on: $3^{\text {rd }}$ of March, 2018 Accepted on: $3^{\text {rd }}$ of April, 2018

(c) Inna Shkolnyk,

Viktoriia Koilo, 2018

Inna Shkolnyk, Dr., Professor, Head of Department of Finance, Banking and Insurance, Sumy State University, Ukraine.

Viktoriia Koilo, Ph.D. Student, Department of Finance, Banking and Insurance, Institute for Business Technologies "Ukrainian Academy of Banking", Sumy State University, Ukraine.

\section{THE RELATIONSHIP BETWEEN EXTERNAL DEBT AND ECONOMIC GROWTH: EMPIRICAL EVIDENCE FROM UKRAINE AND OTHER EMERGING ECONOMIES}

\begin{abstract}
The article examines the relationship between external debt and economic growth in emerging economies for the period 2006-2016. The authors used different econometric tools, e.g., ADL model and correlation analysis. The regression results showed that the original values had no significant impact on the estimation of the parameters. Thus, there was made an assumption that emerging economies have a non-linear impact on macroeconomic parameters, including external debt that has a non-linear type of influence on economic growth. The authors established that high level of external debt, in conjunction with macroeconomic instability, impedes economic growth in such countries. The regression model also showed that there is a critical level of debt burden for emerging economies, where the marginal impact of external debt on economic growth becomes negative.
\end{abstract}

The results of the study highlighted the significance of the problem of effective public debt management strategy implementation in Ukraine. This issue is predetermined by the appropriate organizational support. The study recommends improving a public external debt management model. In this paper, the authors proposed a new structure with the participation of new element - independent agencies. The unified external debt management system should integrate all state institutions and executive power structures in this area.

\section{Keywords}

public external debt, public domestic debt, economic growth, public debt management, ADL model

\section{JEL Classification F34, F43, H63}

\section{INTRODUCTION}

The issue of external borrowing as a policy to promote economic growth creates serious debate among policy makers, researchers and economists. Currently, foreign (external) debt is a global problem for the present and future development of most countries in the world. In particular, this applies to developing economies and emerging economies, including Ukraine.

The main concern is whether or not external borrowing leads to economic growth in emerging economies. Ensuring of the economic development of the country is one of the most important national priorities, being a guarantee of the country's independence, a condition for stability and effective life of the society, achievement of success. According to the main economic theories, external debt should have an influence on the economy through investment and productivity of the labor force. Since the main reason for attracting external loans is a lack of own funds to finance investment projects, an increase in gross external debt should stimulate growth in investment and capital formation, which leads to an increase in the potential volume of GDP. However, often external loans can be used not for investment projects, but for short-term
This is an Open Access article, distributed under the terms of the Creative Commons Attribution-NonCommercial 4.0 International license, which permits re-use, distribution, and reproduction, provided the materials aren't used for commercial purposes and the original work is properly cited. 
goals to cover emerging deficits of the economy. Thus, in economic theory, there are different approaches in evaluating the relationship between external debt and economic growth. On the one hand, the neoclassical growth models advocated that there is a positive influence of the external debt on economic growth. Moreover, they emphasized that borrowings are one of the sources for financing capital formation, and they could promote economic growth. On the other hand, there are followers of the opposite theory who aware that due to debt overhang, there is always a decrease in economic growth of the countries.

The main aim of this empirical investigation is to determine the impact of the external debt on economic growth in countries of the estimated group. Economic growth is measured by the dynamics of real GDP. The object of the study is the relationship between external debt and economic growth in countries with emerging economies.

\section{LITERATURE REVIEW}

The relationship between external debt and economic growth is analyzed in different studies, which are aimed at finding out the effect of influence of debt burden on economic growth in countries with different types of economies.

A brief review of the literature examining such an impact allows to highlight several types of relationship between external debt and economic growth. Thus, it is established that the influence of external debt on economic growth can have a positive, negative and non-linear relationship. There are three groups of theoretical models describing this interaction.

The first group offered supporting evidence for the positive relationship between economic growth and foreign debt. These views are based on the provisions of the Keynesian and neoclassical theory of growth, where external debt contributes to more intensive economic growth, provided the productive use of borrowed funds. This approach was observed by Warner (1992), Easterly (2003) and Cline (1985). Warner (1992) found a positive relationship between external debt and investment. Easterly (2003) also found certain empirical evidence of such an impact. According to Cline (1985), external debt contributes positively to growth. He argued that if marginal productivity of each available external debt is greater than or equal with the principal and the interest payment, external debt will have a positive impact on the economy of the borrowing country.

It is worth mentioning that the majority of existing empirical literature report that external debt adversely affects economic growth. The second group of models is devoted to the analysis of the reasons for the negative impact of a high level of external debt on economic growth. This group of models is based on the theory of "debt overhang" developed by Krugman (1988) in the late 1980s. A debt overhang occurs when the present value of the expected income of a country is less than the accumulated debt. Siddique and Selvanathan (2015) found a negative effect of the external debt level on economic growth of 40 poor countries over the period 1970-2007. Empirical evidence revealed the poor internal and external economic policies as the main causes for the debt overhang problem. In another single country study, Rifaqat and Usman (2012) examined the long-run and short-run impact of external debt on economic growth in Pakistan from 1970 to 2010, considering GNP as a function of annual education expenditures (proxy of human capital), capital, labor force and the external debt. They found that external debt exerts a negative impact on economic growth; clearly indicated that higher external debt discourages economic growth.

The third group of models, the most popular nowadays, considers the non-linear impact of external debt on economic growth, and is represented by eclectic concepts that combine the provisions of the previous two groups of models. This group of models is based on the principles of the Laffer curve. According to Sachs (1986), the central point in this concept is the assumption of the existence of a critical level of external debt after the achievement of which further attraction of foreign loans is impractical. The non-linear form of the relationship is explained by the reduction in the absolute size and efficiency of investments, caused by the tendency to reduce the marginal 


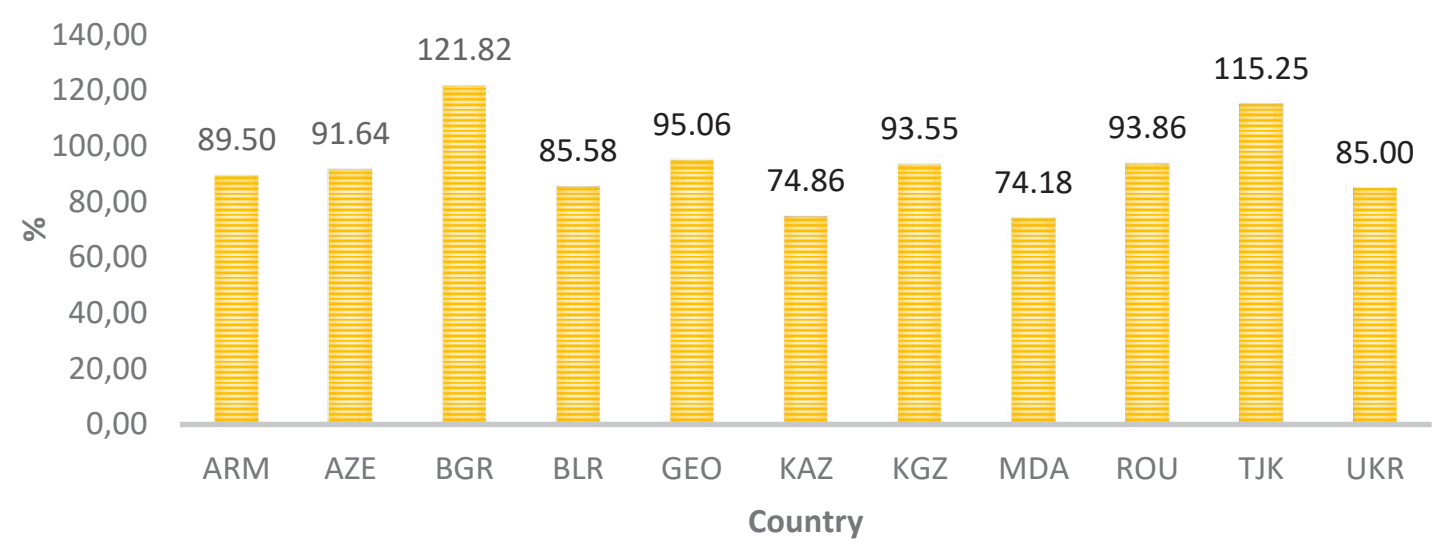

Figure 1. Gini index growth rates in emerging economies (2015 compared with 2005)

efficiency of capital and the impact of unfavorable macroeconomic situation. Emerenini and Nnanna (2015) used a Solow-type neoclassical growth model. The results showed the presence of non-linear effect of debt on economic growth in Nigeria. Soldatova (2006) in her study investigated that external debt contributes positively to growth up to a certain point, after which its contribution becomes negative.

Despite the theoretical study of the problem of public debt and its relationship with the main macroeconomic indicators of the economic growth, there is still a lack of fundamental research on external public debt, in particular, assessment of the ratio of public debt to GDP.

\section{RESEARCH METHODOLOGY}

The following case study is based on the analysis of data of Ukraine and 10 other emerging economies, which had approximately the same economic mechanism, and, at the same time, began to transform their own political and economic systems, namely Armenia, Azerbaijan, Belarus, Bulgaria, Georgia, Kazakhstan, Kyrgyz Republic, Moldova, Romania and Tajikistan.

The reason for including those countries to the estimation group was the availability and the adequacy of comparable reliable data, which were necessary for analysis, and the stability of the socio-political situation in countries during the investigated period. The study period selected was from 2006 to 2016. Data were collected from
World Bank, National Bank of Ukraine, OECD. The study used both descriptive and econometric tools. Parameters are estimated using the nonlinear regression and correlation analysis. The validity of the regression analysis was assessed and Durbin-Watson test was included to check for autocorrelation and included collinearity diagnostics. Pearson's Chi-square test $\chi^{2}$ was applied to sets of categorical data to evaluate how likely it is that any observed difference between the sets arose by chance.

\section{TRENDS AND PATTERNS OF THE EXTERNAL DEBT IN EMERGING ECONOMIES}

The experience of Central European countries shows that macroeconomic stability is a necessary, but insufficient prerequisite for improving the well-being of the population and reducing poverty. If the economy is sensitive to external and internal shock phenomena, in particular, due to excessive external borrowings, the poor and unprotected population is adversely affected.

The market mechanism is not able to provide socially equitable distribution of income, which is generated by the gross product. Unfair income distribution is one of the "defects" of the market system, along with unemployment and inflation. In order to assess how the standard of living in emerging economies has changed over the past 10 years, the authors investigated such an indicator as the Gini index (Figure 1). 


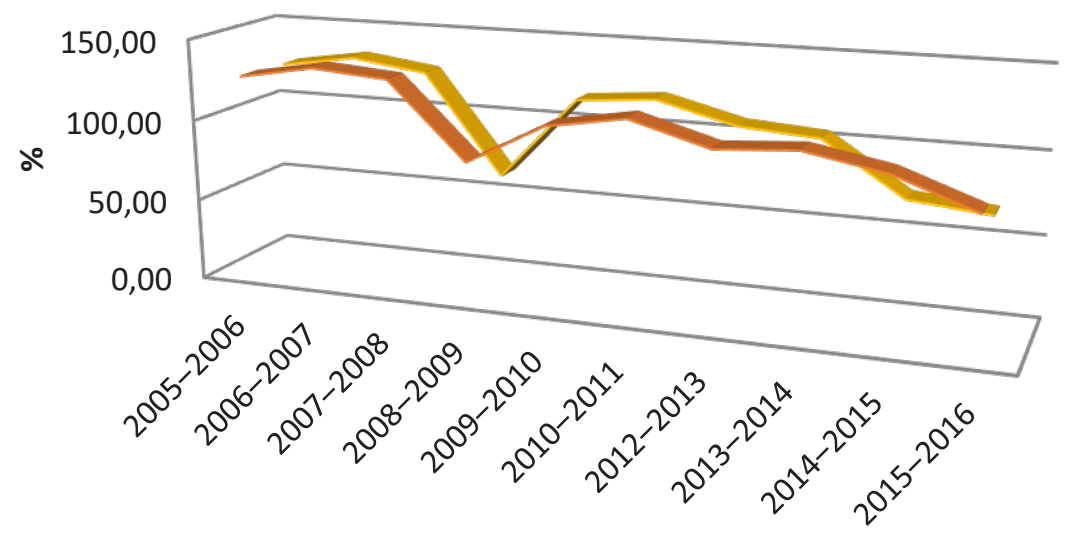

Average annual growth rates of GDP in emerging economies (\%), 2005-2016

Annual growth rates of GDP in Ukraine (\%), 2005-2016

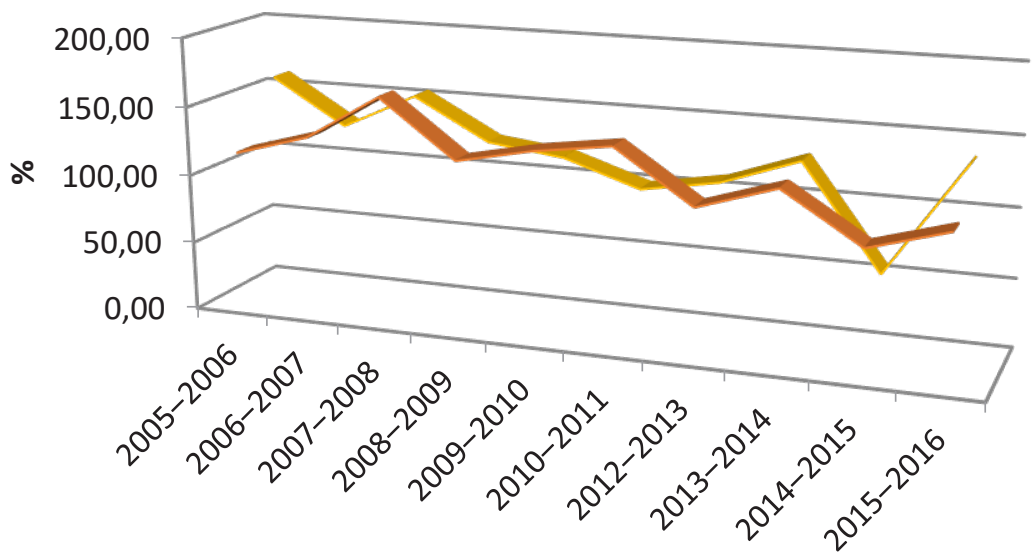

Average annual growth rates of total debt service on external debt in emerging economies (\%), 2005-2016

Annual growth rates of total debt service on external debt in Ukraine (\%), 2005-2016

Figure 2. Annual growth rates of GDP and total debt service on external debt in emerging economies, 2005-2016

The Gini coefficient measures the inequality among values of a frequency distribution (for ext ample, levels of income). A Gini coefficient of zero expresses perfect equality, where all values are the same (where everyone has the same income). A Gini coefficient of $100 \%$ expresses maximal inequality among values.

The results from Figure 1 show that over the past 10 years, in general, the index had a tendency to decrease, except for Bulgaria and Tajikistan. Thus, in emerging economies, there has been an improvement of the fair distribution of income generated by the gross product in recent years.

It should be noted that in international practice, a special place is devoted to the analysis of GDP growth, which is considered as the major indicator of economic growth of the country and plays an extremely important role in determining the development of society. Annual growth rates of GDP and total debt service on external debt in emerging economies are presented in Figure 2.
Figure 2 plots that generally annual growth rates of GDP were almost always higher in the investigated countries than in Ukraine. Moreover, from 2013 to 2016, generally, this indicator has sharply decreased in the group of countries, Ukraine is not exception - the decline by 32\% in 2016 compared with the previous year, whereas, in general, there was a decrease by $18 \%$.

This situation indicates a decline of economic growth in recent years, among the factors - general deterioration of the macroeconomic situation, political problems, military conflict, as well as instability in the international market.

Regarding the dynamics of the ratio of debt servicing to the export of goods and services, the level of payments generally increased, especially in 2016 with a particularly significant level - by $37 \%$ in Ukraine, while in the group - only by $5 \%$.

The matrix of the relationship between external public debt per capita and GDP per capita, depict- 


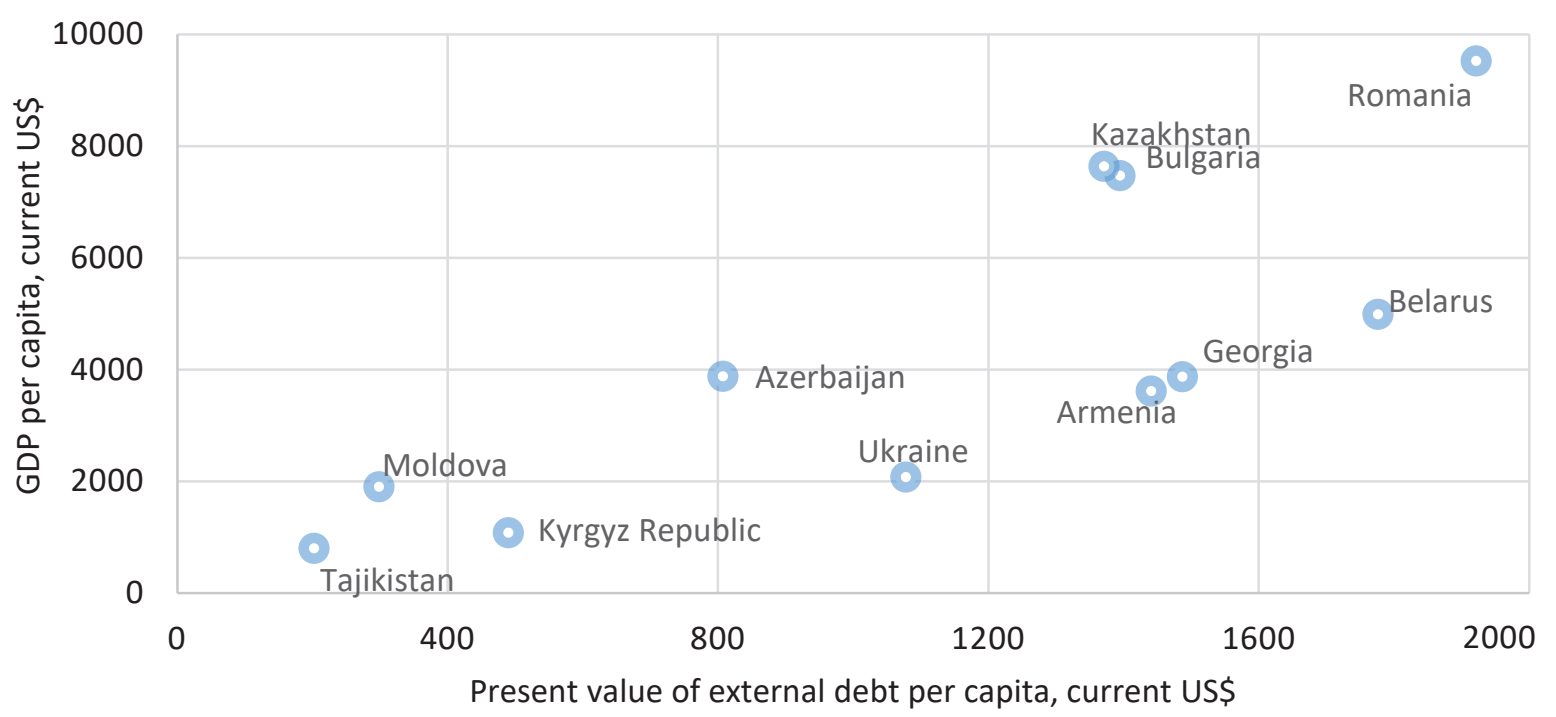

Figure 3. Matrix of correlation of present value of external debt per capita and GDP per capita in emerging economies, 2016

ed in Figure 3, allows to determine in which categories each of the analyzed countries is located.

It should be noted that quite a lot of countries have low GDP and low external debt burden. Romania and Belarus have the highest level of external debt per capita and the value of GDP per capita is the highest in following countries: Romania, Kazakhstan and Bulgaria.

Also it should be mentioned that there are always many risks of using borrowed resources, especially threat for a financial security is the biggest issue for each country. Figure 4 shows that in Ukraine there is a problem of the service of external debt. During the period 2006-2016, the essential exceed of sum of payments on the public external debt over the sum of payments on public domestic debt is observed.

Besides, Figure 4 depicts that in 2015 in Ukraine, there was a rapid and sharp growth in payments on debt in 2015 and a decline in 2016. There is no evidence to suppose that there is a tendency of this parameter.

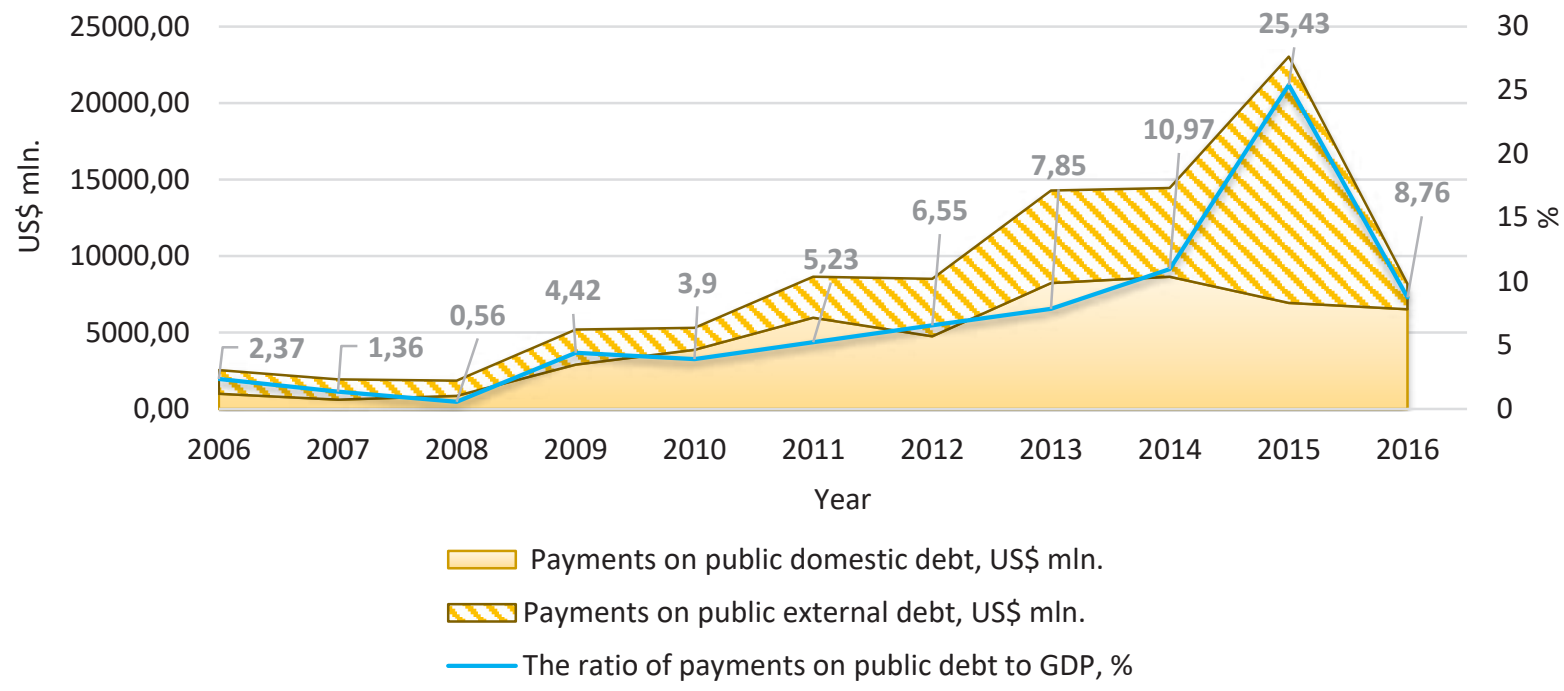

Figure 4. The dynamics of the payments on public domestic debt, payments on the public external debt and the ratio of payment on public debt to GDP in Ukraine, 2006-2016 
This analysis gives the possibility to confirm that Ukraine is the state with high dependence from external financing. In order to optimize the national debt level, it is essential to make its restructuring and concentration on internal credit resources and long-term loans with fixed interest rates.

To analyze the depth of the debt problem, there should be conducted an empirical research that will determine the impact of the external debt on economic growth in countries of the estimated group.

\section{MODEL SPECIFICATION}

In this study, there were estimated both linear and non-linear regressions using a set of variables common in the growth literature. The initial regression analysis, which requires the setting of initial values for each parameter, showed that, in practice, the original values had no significant impact on the estimation of the parameters. Furthermore, the validation of the regression estimates proved that there is no gain of such investigation and no evidence of the adequacy of regression model. Thus, we made a conclusion that emerging economies belong to the third group, where the impact of macroeconomic parameters, including external debt, has a non-linear influence on economic growth.

Therefore, the authors used the non-linear regression to estimate the relationship between external debt of emerging economies and economic growth.

There is no well-defined theoretical framework that sheds light on the relationship between Solow growth model and external debt. But some empirical works on external debt used Solow growth model as a basis to investigate its impact on economic growth. And the model is developed based on Cobb-Douglas production function given by the form:

$$
Y=F(K, L)=K^{\alpha} \cdot L^{1-\alpha} .
$$

Since the investigation of a linear function has undeniable advantages over other classes of functions, the authors reduced non-linear functions to linear ones.
Thus, the power function becomes logical after logarithm of Cobb-Douglas production function:

$$
\begin{aligned}
& \ln Y=\alpha+\beta_{1} \cdot \ln x_{1}+\beta_{2} \cdot \ln x_{2}+ \\
& +\beta_{3} \cdot \ln x_{3}+\ldots+\beta_{n} \cdot \ln x_{n}+\varepsilon
\end{aligned}
$$

where $Y$ is the vector of the rates of economic growth, and $x_{1}, \ldots, x_{n}$ are vectors of potential explanatory variables which can vary from researcher to researcher.

The general model that was estimated in explaining the non-linear relationship between economic growth and macro-economic variables is stated as:

$$
\begin{aligned}
& \ln G D P_{i t}=\beta_{0}+\ln \text { Pop }_{i t}+\ln I n v_{i t}+ \\
& +\ln \text { SNIpercap }_{i t}+\ln U N E_{i t}+\ln E R_{i t}+ \\
& +\ln \text { Open }_{i t}+\ln \operatorname{SExp}_{i t}+\ln \operatorname{RESGdp}_{i t}+ \\
& +\ln \operatorname{EDGdp}_{i t}+u_{i t},
\end{aligned}
$$

where $\ln G D P_{i t}-\log$ of the economic growth for country $i$ between year $t$ and year $t+1 ; \beta_{0}-$ intercept; $\ln$ Pop $_{i t}$ - log of population growth rate; $\ln I n v_{i t}-\log$ of growth rate of investment; $\ln$ GNIpercap $_{i t}$ - log of growth rate of GNI per capita; $\ln E R_{i t}$ - $\log$ of official exchange rate; $\ln U N E_{i t}$ - $\log$ of ratio of unemployment to total labor force; $\ln$ Open $_{i t}$ - log of ratio of the half-sum of exports and imports to GDP; $\ln D S E_{x p}$ - log of debt service export ratio; $\ln R E S G d p_{i t}-\log$ of ratio of total reserves to GDP; $\ln E D G d p_{i t}-\log$ of ratio of external debt to GDP; $u_{i t}$ - error term.

In this study, the authors used as dependent parameter a log of GDP growth and as the main independent variables: log of population growth, $\log$ of growth rate of investment rate (mainly from Solow's growth model), log of growth rate of GNI per capita; log of official exchange rate, log of ratio of unemployment to total labor force, $\log$ of ratio of the half-sum of exports and imports to GDP, log of ratio of total reserves to GDP, and the debt burden measuring variables: the ratio of external debt to GDP, debt service export ratio.

Before inferring conclusion from estimation results, it is important and vital to undertake some statistical tests. This paper tries to take the autocollinearity and multicollinearity tests. 
Multicollinearity: Chi-square test was implemented for the detection of the existence and severity of multicollinearity.

Autocollinearity: another test was used for AR serial correlation - the Durbin-Watson test, based on the OLS residuals.

\section{EMPIRICAL RESULT}

This section shows the estimation results of the model (for all countries in general and each country of the assessed group) and the corresponding test statistics employed in the estimation.

Table 1 depicts the regression analysis of the general model. The coefficient of multiple determinations $\left(\mathrm{R}^{2}\right)$ with the value of 0.966 indicates that the total variation in the GDP growth was accounted for by $96.6 \%$ of the independent variables included in the model. Standard error isn't significant.

Table 1. Overview of model

\begin{tabular}{c|c|c|c|c}
\hline \multicolumn{5}{c}{ Model overview } \\
\hline \multirow{3}{*}{ Model } & $\mathbf{R}$ & $\mathbf{R}^{2}$ & $\begin{array}{c}\text { Adjusted } \\
\mathbf{R}^{2}\end{array}$ & $\begin{array}{c}\text { Standard } \\
\text { error }\end{array}$ \\
\cline { 2 - 5 } & 0.983 & 0.966 & 0.662 & 0.061 \\
\hline
\end{tabular}

Analysis of variance (ANOVA), reported in Table 2 , uses the F-test to determine whether the variability between group means is larger than the variability of the observations within the groups.

Table 2. ANOVA of model

\begin{tabular}{l|c:c:c:c:c}
\hline \multicolumn{7}{c}{ ANOVA } \\
\hline \multicolumn{1}{c}{ Model } & $\begin{array}{c}\text { Sum of } \\
\text { squares }\end{array}$ & $\mathbf{d f}$ & $\begin{array}{c}\text { Mean } \\
\text { square }\end{array}$ & F-test & $\begin{array}{c}\text { F } \\
\text { Sign }\end{array}$ \\
\hline Regression & 0.105 & 9 & 0.012 & 3.18 & 0.411 \\
\hdashline Residue & 0.004 & 1 & 0.004 & - & - \\
\hline
\end{tabular}

The null hypothesis for an ANOVA always assumes the population means are equal. We reject the null hypothesis if $\mathrm{F}$ (observed value) $>\mathrm{F}$ (critical value).

The F-test statistics value is 0.411 , which confirms the presence of at least one independent variable significant for the model.
Table 3 below shows that in the general model, all variables have a positive significant relationship with economic growth. The Durbin-Watson (DW) statistic is a test for serial correlation of residuals of a time series regression. The statistic ranges from 0 to 4 with 0 indicating positive autocorrelation and 4 indicating negative autocorrelation. In our model, DW is 0.029 which is a good indicator of no autocorrelation in the sample. Chisquare test results showed us that $\chi^{2}$ test is less then critical value from the table (test value $<$ table value), then it rejects the existence and severity of multicollinearity.

Table 3. T-test and estimation of regression coefficients for model

\begin{tabular}{|c|c|c|c|}
\hline \multicolumn{4}{|c|}{ Coefficients } \\
\hline \multirow{2}{*}{ Model } & \multicolumn{2}{|c|}{$\begin{array}{l}\text { Non-standardized } \\
\text { coefficients }\end{array}$} & \multirow{2}{*}{$\begin{array}{c}\begin{array}{c}\text { Standardized } \\
\text { coefficients }\end{array} \\
\beta\end{array}$} \\
\hline & t-statistic & p-value & \\
\hline (Constant) & -0.290 & 0.821 & 41.813 \\
\hline In $\mathrm{Pop}_{\mathrm{it}}$ & 0.252 & 0.843 & 9.994 \\
\hline $\ln I n v_{i t}$ & -0.111 & 0.929 & 0.149 \\
\hline In GNIpercap & 0.966 & 0.511 & 1.011 \\
\hline $\ln E_{\text {it }}$ & 0.021 & 0.987 & 0.050 \\
\hline In UNEdp ${ }_{\text {it }}$ & 0.449 & 0.731 & 0.080 \\
\hline In Open & 0.283 & 0.824 & 0.334 \\
\hline In DSExp & 0.256 & 0.841 & 0.108 \\
\hline In RESGdp & 0.064 & 0.960 & 0.303 \\
\hline In EDGdp it & 0.036 & 0.977 & 0.182 \\
\hline$\chi^{2}$ test & 47.715 & $\begin{array}{c}\text { Von } \\
\text { Neumann } \\
\text { criteria }\end{array}$ & 0.032 \\
\hline$\chi^{2}(36 ; 0.05)$ & 50.99 & $\begin{array}{l}\text { Durbin- } \\
\text { Watson }\end{array}$ & 0.029 \\
\hline
\end{tabular}

Empirical findings indicated that population growth rate has the biggest positive effect on economic growth. This means that 1 percent increase in population growth rate leads to increase of GDP by $9.99 \%$. This relationship was significant at 5 percent level of significance. The results also indicated a significant positive relationship between growth rate of GNI per capita and economic growth. This is in line with the general assertion that the capital is a key factor of production, hence, it is positively associated to economic growth. The estimated results showed that 1 percent increase in GNI per capita leads to increase of GDP by 1.01 percent. The relationship was consistent with economic theory. 
Table 4. Correlation matrix

\begin{tabular}{|c|c|c|c|c|c|c|c|c|c|}
\hline & In $\operatorname{Pop}_{i t}$ & $\ln \ln v_{i t}$ & In GNIpercap & In $E R_{i t}$ & $\ln U N E d p_{i t}$ & In Open & In DSExp & $\ln R E S G d p_{i t}$ & $\ln E D G d p_{i t}$ \\
\hline In $P o p_{i t}$ & 1 & 0.237 & 0.109 & 0.308 & 0.044 & -0.619 & -0.126 & -0.429 & -0.055 \\
\hline $\ln I n v_{i t}$ & - & 1 & -0.475 & -0.173 & 0.100 & 0.254 & -0.040 & 0.036 & 0.379 \\
\hline In GNIpercap it & - & - & 1 & 0.146 & 0.180 & -0.223 & 0.116 & 0.272 & -0.211 \\
\hline In $E R_{i t}$ & - & - & - & 1 & 0.365 & -0.361 & 0.545 & 0.098 & 0.062 \\
\hline In $U N E d p_{i t}$ & - & - & - & - & 1 & -0.249 & 0.417 & 0.373 & 0.101 \\
\hline In Open $_{i t}$ & - & - & - & - & - & 1 & -0.263 & 0.505 & 0.357 \\
\hline In DSExp & - & - & - & - & - & - & 1 & -0.043 & 0.144 \\
\hline $\ln R E S G d p_{i t}$ & - & - & - & - & - & - & - & 1 & -0.203 \\
\hline $\ln E D G d p_{i t}$ & - & - & - & - & - & - & - & - & 1 \\
\hline
\end{tabular}

Note: Significance levels are at 5\%.

The result from the general model (for all emerging economies) shows that all the variables in the model are statistically significant. As we hypothesized based on Solow's growth model, growth rate of ratio of the external debt to GDP indicates that $1 \%$ increase in results in the long run increases by $0.18 \%$ of economic growth, but this change is statistically insignificant at $\mathrm{p}$-value of 0.977 , which is greater than $5 \%$.

However, the regression analysis of the model for each country of the estimated group depicts different influence of the external debt (see Table A in Appendix A). For example, debt service export ratio almost in all countries has a positive relationship with economic growth, only in Azerbaijan, Kyrgyz Republic and Moldova, it has negative influence, i.e., $1 \%$ increase in debt service export ratio leads to decline of GDP by $0.27 \%$ in Armenia (but p-value was less than 5\% - 0.287), in Kyrgyz Republic, there was higher level of influence $(-0.85 \%)$ and the greatest effect was in Moldova $(-0.68 \%)$.

The ratio of external debt to GDP was significant at 5 percent and negatively related to GDP in Armenia, Azerbaijan, Belarus, Kazakhstan, Moldova and Ukraine. Indicating that an increase in the external borrowing of those countries affects the economy negatively, i.e., in Ukraine 1\%, increase in ratio of external debt to GDP leads to decrease of GDP by $0.20 \%$. This relationship was significant at 5 percent level of significance ( $p$-value is 0.563 ).
Table 4 below shows the correlation coefficient which indicates the degree of linear relationship between the variables. The findings indicate that growth rate of GNI per capita has a negative correlation with growth rate of investment $-0.475)$; official exchange rate with growth rate of investment (-0.173); openness of economy has negative relation with all indicates, except for the growth rate of investment, while it has a positive effect (0.254); debt service export ratio has a negative correlation with population growth rate $(-0.126)$, growth rate of investment $(-0.040)$, ratio of external debt to GDP $(-0.263)$; ratio of total reserves to GDP with population growth rate $(-0.429)$ and debt service export ratio (-0.043); and ratio of external debt to GDP has a negative relationship with population growth rate $(-0.055)$, growth rate of GNI per capita $(-0.211)$ and ratio of total reserves to GDP $(-0.203)$ at $5 \%$ significant level, respectively.

Next step of the analysis was based on the abovementioned multiple regression model. The authors tried to establish the critical level of external debt, which negatively affects the economic growth of Ukraine. Based on the results obtained from the present empirical investigation, the following conclusions can be drawn: the influence of external debt on the dynamics of GDP is non-linear, the marginal impact of external debt on GDP dynamics becomes negative with the level of external debt $62 \%$, and the GDP growth rate increases twice with $8 \%$ of the level of external debt to GDP. 
Obviously, the orientation of most countries towards the generally accepted (normative) level of external debt accumulation is inaccurate.

\section{RECOMMENDATIONS}

Thus, the conducted empirical testing of the influence of external debt on economic growth confirmed the theoretical assumptions concerning negative effects of the external debt service on the level of the development of the emerging economies. Consequently, it can be assumed that efficient use of external resources can be achieved by reforming the existing institutional structure of external debt management. That means that there is a significant problem of public debt management strategy in Ukraine. This issue is predetermined by the appropriate organizational institutional support. The direct participants in the management of the public debt in Ukraine are the Verkhovna Rada of Ukraine, the Ministry of Finance of Ukraine, one of the main tasks of which is the development of programs for state borrowing and their implementation on behalf of Ukraine, as well as management of public internal and external debt, National Bank of Ukraine (directly deals with the servicing and payment of external debt obligations of the government), the
State Treasury Service of Ukraine (implementation of management of internal and external public debt and its servicing together with the National Bank of Ukraine and the Ministry of Finance), Ministry of Economic Development and Trade of Ukraine, Department for Regulation of Foreign Economic Activities (former National Agency of Ukraine for Reconstruction and Development), State Export-Import Bank of Ukraine (carries out servicing of foreign loans granted by international organizations under government guarantee), State Financial Inspection and Accounting Chamber of Ukraine (regularly informing the Verkhovna Rada of Ukraine and its committees on the progress of the implementation of the State Budget of Ukraine and the state of repayment of Ukraine's internal and external debt).

This structure is not effective, moreover, in many emerging economies, the issue of centralizing public debt management has recently become quite acute. For example, in Kazakhstan and Belarus, there are assumptions that consider the possibility of creating debt agencies.

In general, there are three approaches of constructing the institutional models of the public external debt management adaptable to specific needs, as follows in Table 5.

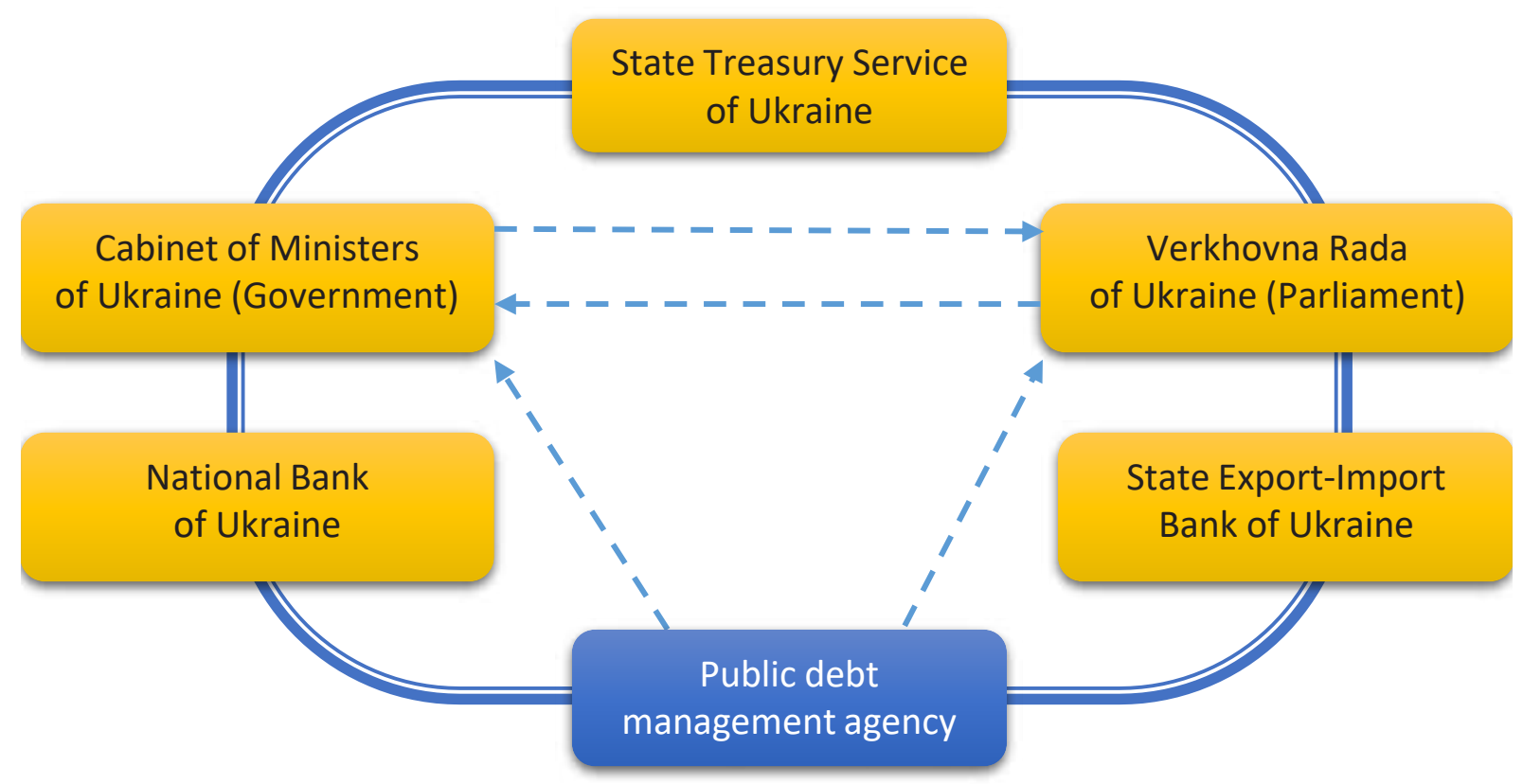

Figure 5. Institutional model of the public external debt management 
Table 5. Institutional models of the external public debt management

\begin{tabular}{|c|c|c|}
\hline No. & Model & Characteristic \\
\hline 1 & $\begin{array}{l}\text { Governmental } \\
\text { (ministerial) } \\
\text { model }\end{array}$ & $\begin{array}{l}\text { the functions of debt management } \\
\text { are located in several ministries and } \\
\text { departments; } \\
\text { the goals of debt management are set } \\
\text { and achieved with budget policy }\end{array}$ \\
\hline 2 & Bank model & $\begin{array}{l}\text { the functions of debt management are } \\
\text { contained in the central bank; } \\
\text { public debt management (goals, } \\
\text { objectives, strategies, operations) is } \\
\text { subordinated mainly to the purpose of } \\
\text { monetary policy }\end{array}$ \\
\hline 3 & Agency model & $\begin{array}{l}\text { the functions of debt management are } \\
\text { located in one independent institution; } \\
\text { high level of transparency of the } \\
\text { agency's activities; } \\
\text { multi-stage audit and monitoring of } \\
\text { agency activities; } \\
\text { operational goals and public debt } \\
\text { management strategies are developed } \\
\text { and implemented by the agency with } \\
\text { the relevant ministerial approval }\end{array}$ \\
\hline
\end{tabular}

The first and the second approaches are united by one common principle feature - the management of external debt is built on the basis of traditional institutions of government administration.

Regarding the third approach, it should be noted that, as practice has shown, independent agencies alone do not guarantee the automatic creation of an effective management system. Meanwhile, in countries where such a structure was organized, it was possible to solve, on the one hand, the problem of the growing volume of external debt, and on the other hand, there appeared the problem of attracting highly qualified personnel to the civil service in such agencies.

The authors have developed own approximate structures of the institutional model in the field of public external debt management, which is presented in Figure 5.

This model is simplified, therefore, more effective, since the functions of the bodies are not duplicated, and are concentrated mainly in such a link as the debt agency. It must function with the relevant Government and Parliament approval and realize the goals through debt service bodies (National Bank of Ukraine, State Treasury Service of Ukraine and State Export-Import Bank of Ukraine).

It should be noted that in Medium-Term Government Priority Action Plan up to 2020, approved by the Ordinance of the Cabinet of Ministers of Ukraine in 2017 No. 142-p, it was mentioned about strengthening institutional capacity for strategic planning, but there are not any issues concerning an adequate institutional model of debt management adapted to the needs of the country.

At this stage, the solution of the problem of improving the management of external debt should not be reduced only to the problem of organizing a debt agency. The unified external debt management system should integrate all state institutions and executive power structures in this area.

\section{CONCLUSION}

According to the author's research results, external resources have become an important source of the additional investment. However, the improper policy of external debt management and the inefficient use of external resources have a negative impact on the dynamics of economic development.

According to data analysis, the following conclusions can be obtained: external debt has a non-linear relationship on the dynamics of GDP in emerging economies; there is a marginal impact of external debt on GDP dynamics; the efficient use of external resources can be achieved by reforming the existing institutional structure of external debt management.

The regression model can be practically used as one of the tools in creating the state's macroeconomic policy. The use of the model will allow to analyze the impact of foreign economic debt on economic growth. The developed regression model allows to choose one or another model tool, in accordance with the current situation in the world economic system, managing such important factors as investments, population, reserves, openness of the economy, etc. 
The application of the regression model partially will allow to solve the problem of "debt overhang". Based on the economic and statistical analysis of the interaction of model parameters, it can be concluded that the function of the dependence of external debt on GDP can be used as a decision-making tool in the economic policy of the country.

\section{ACKNOWLEDGEMENT}

The article presents the authors' results of the study, which were conducted within the confines of the Ministry of Education and Science of Ukraine (Formation of a system of transparency of public finances as a precondition for fighting corruption in Ukraine, state registration number 0118U003585).

\section{REFERENCES}

1. Arapova, E. Ya. (2016). Регионализация в Восточной Азии в условиях диверсификации источников экономического роста [Regionalizatsiya $v$ Vostochnoy Azii v usloviyakh diversifikatsii istochnikov ekonomicheskogo rosta] (232 p.). Moscow: Prospekt.

2. Ataev, A. M. (2012)

Теоретические аспекты воздействия внешнего долга на динамику экономического роста [Теоreticheskie aspekty vozdeystiviya vneshnego dolga na dinamiku ekonomicheskogo rosta]. Gosudartvennoe i munitsipalnoe upravlenie, 1, 211-218.

3. Beretta, E. (2012). The economics of external debt: a Damocles' Sword hanging over the Emergent and the Virtuous (Germany). Banks and Bank Systems, 7(2). Retrieved from https://ssl.lu.usi.ch/ entityws/Allegati/pdf_pub6406.pdf

4. Cline, W. R. (1995). International Debt Re-examined. Washington DC: Peterson Institute for International Economics.

5. Dash, M. (2016). A study of regional trends in external debt in developing economies. Investment Management and Financial Innovations, 13(3). http://dx.doi. org/10.21511/imfi.13(3).2016.02

6. Easterly, W. (2003). The political economy of growth without development: A case study of Pakistan. In Dani Rodrik (Ed.), Analytic Narratives on Economic Growth. Princeton: Princeton University Press.
7. Ejigayehu, D. A. (2013). The Effect of External Debt On Economic growth. Retrieved from http:// www.diva-portal.org/smash/get/ diva2:664110/FULLTEXT01.pdf

8. Emanuele Baldacci, Iva Petrova, Nazim Belhocine, Gabriela Dobrescu, \& Samah Mazraani (2011, May). Assessing Fiscal Stress (IMF Working Paper). Retrieved from http://www.imf.org

9. Emerenini, F. M., Nnanna, A. U. (2015). Debt Management and Economic Growth Empirical Evidence from Nigeria. International Journal of Innovative Research \& Development, 4(1), 243-258.

10. Fasolko, T. M. (2014). Моделювання взаємозв'язку між державним боргом та економічним зростанням [Modeliuvannia vzaemozvazku mizh derzhavnym borhom ta ekonomichnym zrostanniam]. Aktualni problemy ekonomiky, 5, 548-555.

11. Fleichuk, M., Andrusiv, R. (2012). Влияние внешних заимствований на социальноэкономическое развитие посттрансформационных стран [Vliyanie vneshnikh zaimstvovaniy na sotsialno-ekonomisheskoe razvitie posttransformatsyonnykh stran]. Ekonomika Ukrainy, 1, 16-26.

12. Ijirshar, V. U., Joseph, F., Godoo, M. (2016). The Relationship between External Debt and Economic Growth in Nigeria. Int J Econ Manag Sci, 6, 390. http://dx.doi. org/10.4172/2162-6359.1000390
13. Jilenga, M. T., Xu, H., \& GondjeDacka, I. M. (2016). The Impact of External Debt and Foreign Direct Investment on Economic Growth: Empirical Evidence from Tanzania. International Journal of Financial Research, 7(2), 154-162.

14. Khoury, E. L., Colmant, B., \& Corhay, A. (2009). Predicting default probability and the default recovery ratio: evidence from the Lebanese external public debt. Banks and Bank Systems, 4(2). Retrieved from https:// businessperspectives.org/images/pdf/applications/publishing/ templates/article/assets/2744/ BBS_en_2009_2_Khoury.pdf

15. Kızılgöl, Ö. A., \& Evren İpek (2014). An Empirical Evaluation of the Relationship between Trade Openness and External Debt: Turkish Case. International Econometric Review (IER), 42-58.

16. Krugman, P. R. (1988). Financing versus Forgiving a Debt overhang. Journal of Development Economics, 29, 253-268.

17. Lane, P. R. (2004). Empirical Perspectives on Long-Term External Debt. The B.E. Journal of Macroeconomics, De Gruyter, 4(1), 1-23.

18. Medium-Term Government Priority Action Plan up to 2020 APPROVED by the Ordinance of the Cabinet of Ministers of Ukraine of 2017 No. 142-p. Retrieved from https://www.kmu.gov.ua/ua/ npas/249797370

19. Paleshko, Ya. S. (2014). Міжнародний досвід управління 
державною заборгованістю [Mizharodnyi dosvid upravlinnia derzhavnoiu zaborhovanistu]. Ekonomichnyi prostir, 92, 34-44.

20. Rifaqat, A., \& Usman, M. (2012). External Debt Accumulation and Its Impact on Economic Growth in Pakistan. The Pakistan Development. Review, 51(4), 79-96.

21. Sachs, J. D. (1986). The Debt Overhang Problem of Developing Countries. Memorial to Carlos Diaz-Alejandro, Helsinki.

22. Seroka-Stolka, O., LukomskaSzarek, J. (2016). Public debt management in Poland compared to other countries of the European Union (pp. 237-246). 3rd Business \& Management Conference, Lisbon. Preliminary version, IISES.

23. Shymanovich, G. (2011). Факторы роста валового внешнего долга Беларуси [Faktory rosta valovogo vneshnego dolga Belarusi]. Bankauski Vesnik, 19(258), 48-54.

24. Siddique, A., Selvanathan, S. (2015). The impact of external debt on economic growth: empirical evidence from highly indebted poor countries (31 p.) (Discussion paper). University of Western Australia. Business School Economics.

25. Soldatova, E. I. (2005). Воздействие внешней задолженности на социальноэкономическое развитие государств [Vozdeystvie vneshney zadolzhennosti na sotsialno-ekonomicheskoe razvitie gosudarstv]. Moscow: IIT MGUS.

26. Soldatova, E. I. (2006). Суизествует лиоптимум внешнеэкономической задолженности? [Suschestvuet li optimum vneshneekonomicheskoy zadolzhennosti?] Teoreticheskie i prikladnye problemy servisa, 4.

27. United Nations Economic Commission for Europe (2012). Gross external debt, millions of US Dollars - Germany. Switzerland: UNECE Statistical Division Database. Retrieved from http://w3.unece. org/pxweb/?lang=1

28. Warner, A. M. (1992). Did the Debt Crisis Cause the Investment Crisis? Quarterly Journal of Economics, 107(4), 1161-1186.

29. World Bank (2017). World Development Indicators 2017. Washington, DC: World Bank. Retrieved from https://data.worldbank.org/ indicator 


\section{APPENDIX A}

Table A. Fixed effects panel regression for each variable in each country, 2006-2016

\begin{tabular}{|c|c|c|c|c|c|c|c|c|c|c|c|c|}
\hline \multirow[b]{2}{*}{ Variable } & \multicolumn{4}{|c|}{ Armenia } & \multicolumn{4}{|c|}{ Azerbaijan } & \multicolumn{4}{|c|}{ Belarus } \\
\hline & 遏 & 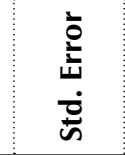 & & 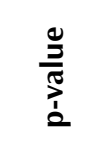 & 过 & 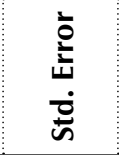 & 苞 & $\begin{array}{l}\frac{0}{2} \\
\frac{0}{2} \\
\frac{1}{2}\end{array}$ & 选 & 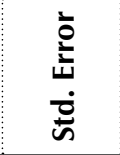 & & $\begin{array}{l}\frac{0}{\frac{D}{\pi}} \\
\frac{\sqrt{2}}{2} \\
2\end{array}$ \\
\hline $\ln G D P_{j t . .}$ & -120.413 & 3346.380 & -0.348 & 0.787 & 67.690 & 63.479 & 1.066 & 0.480 & 408.163 & 149.796 & 2.725 & 0.224 \\
\hline $\ln P o p_{i t}$ & 23.441 & 71.000 & 0.330 & 0.797 & -14.385 & 13.465 & -1.068 & 0.479 & -91.725 & 33.364 & -2.749 & 0.222 \\
\hline $\ln \ln v_{i t \ldots .}$ & 0.209 & 0.407 & 0.512 & 0.699 & -0.053 & 0.130 & -0.407 & 0.754 & 0.044 & 0.029 & 1.506 & 0.373 \\
\hline In GNIpercap & 2.471 & 2.921 & 0.846 & 0.553 & -0.836 & 0.811 & -1.031 & 0.490 & -1.236 & 0.501 & -2.469 & 0.245 \\
\hline In $E R_{i t \ldots .}$ & -0.079 & 1.506 & -0.052 & 0.967 & -1.234 & 0.735 & -1.679 & 0.342 & -2.978 & 0.638 & -4.667 & 0.134 \\
\hline In UNEdp & 1.842 & 4.031 & 0.457 & 0.727 & -1.188 & 2.636 & -0.451 & 0.730 & -3.405 & 0.542 & -6.285 & 0.100 \\
\hline In Open & -0.340 & 4.929 & -0.069 & 0.956 & 2.538 & 1.111 & 2.284 & 0.263 & 3.629 & 0.765 & 4.742 & 0.132 \\
\hline In DSExp & 0.136 & 0.480 & 0.284 & 0.824 & -0.273 & 0.133 & -2.062 & 0.287 & 3.594 & 0.943 & 3.811 & 0.163 \\
\hline In RESGdp & 0.202 & 0.718 & 0.281 & 0.826 & 0.174 & 0.639 & 0.272 & 0.831 & -0.699 & 0.190 & -3.674 & 0.169 \\
\hline \multirow[t]{5}{*}{ In $E D G d p_{i t}$} & 0.008 & 0.116 & 0.069 & 0.956 & -0.081 & 0.120 & -0.678 & 0.621 & -0.097 & 0.023 & -4.186 & 0.149 \\
\hline & $R^{2}=$ & & 0.979 & & $R^{2}=$ & & 0.987 & & $R^{2}=$ & & 0.970 & \\
\hline & $\operatorname{adj} R^{2}=$ & & 0.795 & & $\operatorname{adj} R^{2}=$ & & 0.868 & & $\operatorname{adj} R^{2}=$ & & 0.034 & \\
\hline & F-test & & 5.301 & & F-test & & 8.338 & & F-test & & 36.498 & \\
\hline & F Sign & & 0.326 & & F Sign & & 0.263 & & F Sign & & 0.128 & \\
\hline & \multicolumn{4}{|c|}{ Bulgaria } & \multicolumn{4}{|c|}{ Georgia } & \multicolumn{4}{|c|}{ Kazakhstan } \\
\hline Variable & 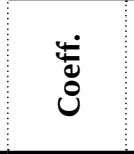 & 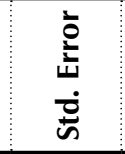 & 䓪 & $\frac{\frac{0}{2}}{\frac{1}{1}}$ & ن & $\begin{array}{l}\dot{\vdots} \\
\text { ò } \\
\dot{2} \\
\dot{0}\end{array}$ & 苞 & $\frac{\frac{0}{3}}{\sqrt[T]{3}}$ & 遏 & $\begin{array}{l}\dot{\vdots} \\
\text { ò } \\
\dot{2} \\
\dot{0}\end{array}$ & & $\frac{\frac{0}{3}}{\frac{3}{1}}$ \\
\hline $\ln G D P_{j t .}$ & 967.704 & 341.834 & 2.831 & 0.216 & -409.504 & 325.479 & -1.258 & 0.428 & 51.402 & 69.117 & 0.744 & 0.593 \\
\hline In $P o p_{i t . .}$ & -209.397 & 73.956 & -2.831 & 0.216 & 88.817 & 70.959 & 1.252 & 0.429 & -14.658 & 13.061 & -1.122 & 0.463 \\
\hline $\ln \ln v_{i t \ldots .}$ & -0.085 & 0.173 & -0.494 & 0.708 & 0.710 & 0.427 & 1.661 & 0.345 & 0.238 & 0.180 & 1.323 & 0.412 \\
\hline In GNIpercap & -0.827 & 1.961 & -0.422 & 0.746 & 1.955 & 1.312 & 1.491 & 0.376 & 2.764 & 2.476 & 1.116 & 0.465 \\
\hline $\ln E R_{i t . .}$ & -2.311 & 1.207 & -1.914 & 0.306 & -5.491 & 3.518 & -1.561 & 0.363 & 0.922 & 1.317 & 0.700 & 0.611 \\
\hline In $U N E d p_{i t . .}$ & 0.232 & 0.454 & 0.512 & 0.699 & -0.379 & 1.108 & -0.342 & 0.790 & -2.073 & 1.407 & -1.473 & 0.380 \\
\hline In Open & 0.885 & 0.888 & 0.996 & 0.501 & -1.494 & 1.607 & -0.930 & 0.523 & 0.657 & 0.768 & 0.855 & 0.550 \\
\hline In DSExp & 0.047 & 0.307 & 0.152 & 0.904 & 0.030 & 0.205 & 0.145 & 0.909 & 0.614 & 0.479 & 1.281 & 0.422 \\
\hline In RESGdp & 0.212 & 0.733 & 0.290 & 0.820 & 1.185 & 0.828 & 1.432 & 0.388 & 0.461 & 0.382 & 1.205 & 0.441 \\
\hline \multirow[t]{5}{*}{ In $E D G d p_{i t \ldots}$} & 0.054 & 0.121 & 0.445 & 0.733 & 0.241 & 0.347 & 0.694 & 0.614 & -0.220 & 0.193 & -1.143 & 0.457 \\
\hline & $R^{2}$ & & 0.972 & & $R^{2}$ & & 0.920 & & $\mathrm{R}^{2}$ & & 0.920 & \\
\hline & $\operatorname{adj} R^{2}$ & & 0.715 & & $\operatorname{adj} R^{2}$ & & 0.202 & & $\operatorname{adj} R^{2}$ & & 0.202 & \\
\hline & F-test & & 3.792 & & F-test & & 1.281 & & F-test & & 3.304 & \\
\hline & F Sign & & 0.380 & & F Sign & & 0.600 & & F Sign & & 0.600 & \\
\hline
\end{tabular}


Table A. (cont). Fixed effects panel regression for each variable in each country, 2006-2016

\begin{tabular}{|c|c|c|c|c|c|c|c|c|c|c|c|c|}
\hline \multirow[b]{2}{*}{ Variable } & \multicolumn{4}{|c|}{ Kyrgyz Republic } & \multicolumn{4}{|c|}{ Moldova } & \multicolumn{4}{|c|}{ Romania } \\
\hline & 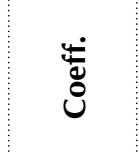 & $\begin{array}{l}\dot{亠} \\
\frac{\grave{L}}{4} \\
\dot{0} \\
\dot{\omega}\end{array}$ & & $\frac{\frac{0}{2}}{\frac{3}{J}}$ & $\begin{array}{l}\stackrel{4}{ \pm} \\
\dot{U}\end{array}$ & 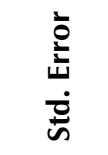 & & $\frac{\frac{0}{2}}{\frac{\pi}{2}}$ & $\begin{array}{l}\stackrel{\leftarrow}{ \pm} \\
\dot{U}\end{array}$ & 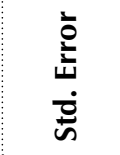 & & 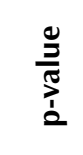 \\
\hline In GDPit & -1678.171 & 2738.420 & -0.613 & 0.650 & 143.885 & 5.039 & 28.552 & 0,022 & -555.739 & 278.850 & -1.993 & 0.296 \\
\hline In Popit & 400.590 & 643.521 & 0.622 & 0.646 & -32.180 & 1.089 & -29.555 & 0,022 & 121.508 & 60.890 & 1.996 & 0.296 \\
\hline In Invit & -0.741 & 1.095 & -0.677 & 0.621 & -0.145 & 0.002 & -64.072 & 0,010 & -0.065 & 0.171 & -0.380 & 0.769 \\
\hline In GNIpe & -25.725 & 34.351 & -0.749 & 0.591 & 1.527 & 0.010 & 154.486 & 0,004 & 1.173 & 1.280 & 0.916 & 0.528 \\
\hline In ERit & -22.725 & 33.048 & -0.688 & 0.617 & 0.370 & 0.008 & 46.029 & 0,014 & -4.316 & 1.872 & -2.305 & 0.261 \\
\hline In UNEdpit & 10.218 & 20.093 & 0.509 & 0.700 & -0.095 & 0.002 & -42.382 & 0,015 & -3.591 & 1.937 & -1.854 & 0.315 \\
\hline In Openit & 7.160 & 6.995 & 1.024 & 0.493 & 0.990 & 0.011 & 93.180 & 0,007 & 1.050 & 0.536 & 1.959 & 0.300 \\
\hline In DSExpit & -0.850 & 1.058 & -0.803 & 0.569 & -0.689 & 0.006 & -114.739 & 0,006 & 0.434 & 0.447 & 0.972 & 0.509 \\
\hline In RESGdpit & -1.784 & 2.634 & -0.677 & 0.621 & -0.070 & 0.006 & -12.061 & 0,053 & 0.916 & 0.530 & 1.729 & 0.334 \\
\hline \multirow[t]{5}{*}{ In EDGdpit } & 1.217 & 1.737 & 0.700 & 0.611 & -0.069 & 0.002 & -40.792 & 0,016 & 0.249 & 118 & 2.103 & 0.283 \\
\hline & $R^{2}$ & \multicolumn{3}{|c|}{0.865} & $R^{2}$ & \multicolumn{3}{|c|}{1.000} & $R^{2}$ & \multicolumn{3}{|c|}{0.978} \\
\hline & $\operatorname{adj} R^{2}$ & \multicolumn{3}{|c|}{-0.347} & $\operatorname{adj} R^{2}$ & \multicolumn{3}{|c|}{1.000} & $\operatorname{adj} R^{2}$ & \multicolumn{3}{|c|}{0.779} \\
\hline & F-test & \multicolumn{3}{|c|}{0.714} & F-test & \multicolumn{3}{|c|}{13707.434} & F-test & \multicolumn{3}{|c|}{4.928} \\
\hline & \multicolumn{4}{|c|}{0.733} & F Sign & \multicolumn{3}{|c|}{0.007} & F Sign & \multicolumn{3}{|c|}{0.337} \\
\hline & \multicolumn{4}{|c|}{ Tajikistan } & \multicolumn{4}{|c|}{ Ukraine } & \multicolumn{4}{|c|}{ Total } \\
\hline Variable & $\begin{array}{l}\stackrel{4}{ \pm} \\
\dot{0}\end{array}$ & 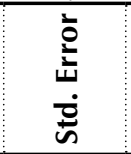 & 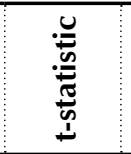 & $\frac{\frac{0}{3}}{\frac{3}{\pi}}$ & 苞 & 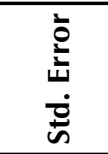 & 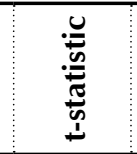 & $\frac{\mathscr{0}}{\frac{0}{\pi}}$ & $\begin{array}{l}\stackrel{\mathscr{J}}{\Xi} \\
\dot{U}\end{array}$ & $\begin{array}{l}\frac{1}{2} \\
\frac{1}{4} \\
\dot{0} \\
\dot{\omega}\end{array}$ & 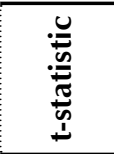 & $\begin{array}{l}\frac{0}{2} \\
\frac{2}{2} \\
2\end{array}$ \\
\hline In GDPit & 1273.330 & 9.460 & 134.599 & 0.005 & 471.980 & 367.961 & 1.283 & 0.422 & -12.111 & 41.813 & -0.290 & 0.821 \\
\hline In Popit & -269.493 & 2.018 & -133.557 & 0.005 & -104.886 & 79.869 & -1.313 & 0.414 & 2.515 & 9.994 & 0.252 & 0.843 \\
\hline In Invit & 0.045 & 0.000 & 206.935 & 0.003 & -0.085 & 0.096 & -0.886 & 0.538 & -0.017 & 0.149 & -0.111 & 0.929 \\
\hline In GNIpercapit & -0.072 & 0.005 & -13.993 & 0.045 & 1.825 & 1.380 & 1.323 & 0.412 & 0.977 & 1.011 & 0.966 & 0.511 \\
\hline In ERit & -1.232 & 0.011 & -114.408 & 0.006 & 1.334 & 1.010 & 1.320 & 0.413 & 0.001 & 0.050 & 0.021 & 0.987 \\
\hline In UNEdpit & -10.511 & 0.057 & -184.298 & 0.003 & -2.251 & 2.385 & -0.944 & 0.518 & 0.036 & 0.080 & 0.449 & 0.731 \\
\hline In Openit & 1.207 & 0.006 & 187.335 & 0.003 & 1.685 & 0.956 & 1.762 & 0.329 & 0.094 & 0.334 & 0.283 & 0.824 \\
\hline In DSExpit & 0.471 & 0.003 & 142.129 & 0.004 & 0.312 & 0.371 & 0.841 & 0.555 & 0.028 & 0.108 & 0.256 & 0.841 \\
\hline In RESGdpit & -0.190 & 0.001 & -176.132 & 0.004 & 0.468 & 0.211 & 2.214 & 0.270 & 0.019 & 0.303 & 0.064 & 0.960 \\
\hline \multirow[t]{5}{*}{ In EDGdpit } & 0.030 & 0.001 & 35.897 & 0.018 & -0.208 & 0.253 & -0.820 & 0.563 & 0.006 & 0.182 & 0.036 & 0.977 \\
\hline & $R^{2}$ & \multicolumn{3}{|c|}{1.000} & $R^{2}$ & \multicolumn{3}{|c|}{0.989} & $R^{2}$ & \multicolumn{3}{|c|}{0.966} \\
\hline & $\operatorname{adj} R^{2}$ & \multicolumn{3}{|c|}{1.000} & $\operatorname{adj} R^{2}$ & \multicolumn{3}{|c|}{0.894} & $\operatorname{adj} R^{2}$ & \multicolumn{3}{|c|}{0.662} \\
\hline & F-test & & 8564.492 & & F-test & & 10.360 & & F-test & & 3.180 & \\
\hline & F Sign & & 0.003 & & F Sign & & 0.237 & & F Sign & & 0.411 & \\
\hline
\end{tabular}

